\title{
Effect of Different Plant Growth Regulators and their Levels on Floral Yield and Economics of China Aster [Callistephus chinensis (L.) Nees] cv. Shashank
}

\author{
Mamilla Sindhuja ${ }^{1}$ and V.M. Prasad ${ }^{2}$ \\ ${ }^{1}$ (Ag.) Horti. (Floriculture and Landscaping), Department of Horticulture, SHUATS, \\ Allahabad, India \\ ${ }^{2}$ Department of Horticulture, SHUATS, Allahabad, India \\ *Corresponding author
}

\begin{abstract}
A B S T R A C T
Keywords

China aster, $\mathrm{GA}_{3}$, NAA, CCC

Article Info

Accepted:

10 November 2018

Available Online:

10 December 2018

A field experiment was carried out to evaluate response of plant growth regulators on flowering and economics of China aster cv. Shashank under taken at Department of Horticulture, Naini Agriculture Institute, Sam Higginbottom university of Agriculture, Technology and Sciences (SHUATS), Allahabad during the year 2016-17. The experiment was laid out in RBD (Randomized Block Design) with 13 treatments combination consisting of the thirteen treatments comprised of control, $\mathrm{GA}_{3}(50,100,150$ and $200 \mathrm{ppm}$ respectively), NAA $(50,100,150$ and $200 \mathrm{ppm})$ and CCC (500,1000, 1500 and $2000 \mathrm{ppm}$ respectively). The results of the study revealed that floral attributes like number of flowers per plant (71.54), flower weight (5.5g), flower yield per plant(393.42g), flower yield per plot $(4,721.04 \mathrm{~g})$, flower yield per hectare $(12.58 \mathrm{t})$, Cost of cultivation $\left(1,18,739 \mathrm{Rs}^{\mathrm{n}} \mathrm{ha}^{-1}\right)$, Gross Return $\left(6,29,473 \mathrm{Rs}^{-1} \mathrm{a}^{-1}\right)$, Net Return $\left(5,10,734 \mathrm{Rs} \mathrm{ha}^{-1}\right)$ and Benefit Cost Ratio 5.30:1 respectively the best results was recorded by the application of $\mathrm{GA}_{3}$ at $200 \mathrm{ppm}$.
\end{abstract}

\section{Introduction}

Callistephus chinensis is to be considered as one of the important commercial flower $(2 n=18)$ belongs to family Asteraceae and native to China. Its generic name Callistephus is derived from two Greek words Kallosbeauty and stephonusa crown allowing large colourful flower heads. Asters have been developed from single form of wild species Callistephus chinensis (Nandre et al., 2009). The growth and yield of the plant is mainly influenced by two principle factors viz., genetic and management factors. In recent years, scientists have paid due attention to the idea of regulating plant growth by means of growth regulators as third most important factor in improving growth, yield and flowers quality in various ways. These substances modify the plant system, which ultimately affects plant growth and development. Synthetic growth regulating chemicals are become very popular in order to enhance the growth and development of flower crops. Keeping these points in view, the present study was under taken to ascertain the most 
suitable concentration of $\mathrm{GA}_{3}$, NAA and CCC for better growth, yield and quality of China aster (Kumar et al., 2017).

\section{Materials and Methods}

The present investigation entitled "Effect of different plant growth regulators and their levels on floral yield and Economics of China aster [Callistephus chinensis (L.) Nees] cv. Shashank" was carried out under Allahabad agro climatic conditions at the experimental field of the Department of Horticulture, Allahabad school of Agriculture, Sam Higginbottom University of Agriculture, Technology and Sciences, Allahabad (U.P) in the month of November to March during the Rabi season of the year 2016-2017. It is located on latitude of $20^{\circ}$ and $15^{\circ}$ North and longitude of $60^{\circ}$ and 30 East and at an altitude of 98 meters above mean sea level (MSL). The experimental plot was homogenous in fertility having assured irrigation and other required facilities. The soil of experimental field had sandy loam texture, acidic $\mathrm{pH} 7.2$ and organic carbon content $0.44 \%$.

The experiment was laid out in randomized complete block design with three replications. The thirteen treatments comprised of control, $\mathrm{GA}_{3}(50,100,150$ and $200 \mathrm{ppm}$ respectively), NAA (50, 100, 150 and $200 \mathrm{ppm})$ and CCC (500, 1000, 1500 and $2000 \mathrm{ppm}$ respectively).
One month old uniform sized seedlings of China aster were transplanted at a spacing of $40 \mathrm{~cm} \times 60 \mathrm{~cm}$ with a twelve plants in each plot. Solutions of $\mathrm{GA}_{3}$, NAA and CCC at different concentrations were prepared in $1000 \mathrm{ml}$ volumetric flask by dissolving calculated quantity of chemicals in small quantity of ethyl alcohol and then volume was made up to one litre with distilled water. The prepared solutions were sprayed uniformly over the treatments immediately after preparation at 15 and 30 days after transplanting. Observations on different flowering attributes and quality were recorded and analyzed statistically.

\section{Results and Discussion}

Yield parameters like number of flowers per plant (71.54), flower weight $(5.5 \mathrm{~g})$, flower yield per plant(393.42g), flower yield per plot $(4,721.04 \mathrm{~g})$, flower yield per hectare (12.58t), Cost of cultivation $(1,18,739$ Rs. ha $\left.^{-1}\right)$, Gross Return $\left(6,29,473\right.$ Rs.ha $\left.^{-1}\right)$, Net Return (5,10,734Rs.ha $\left.{ }^{-1}\right)$ and Benefit Cost Ratio 5.30:1 respectively the best results was recorded by the application of $\mathrm{GA}_{3}$ at 200 $\mathrm{ppm}$. Increase in weight of flower in treated plants may be attributed to the fact that $\mathrm{GA}_{3}$ promotes the efficacy of plants in terms of photosynthetic activity, uptake of nutrients and their translocation, better partitioning of assimilates into reproductive parts.

Figure.1 Effect of different plant growth regulators on Flower weight (g) of China aster cv. Shashank

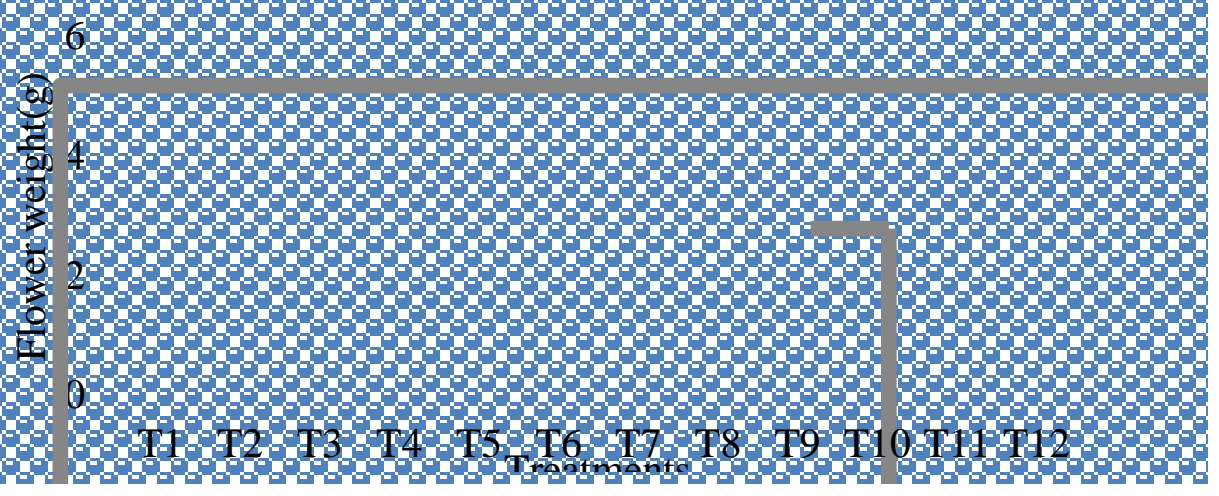


Figure.2 Effect of different plant growth regulators on Number of flowers per plant of China aster cv. Shashank

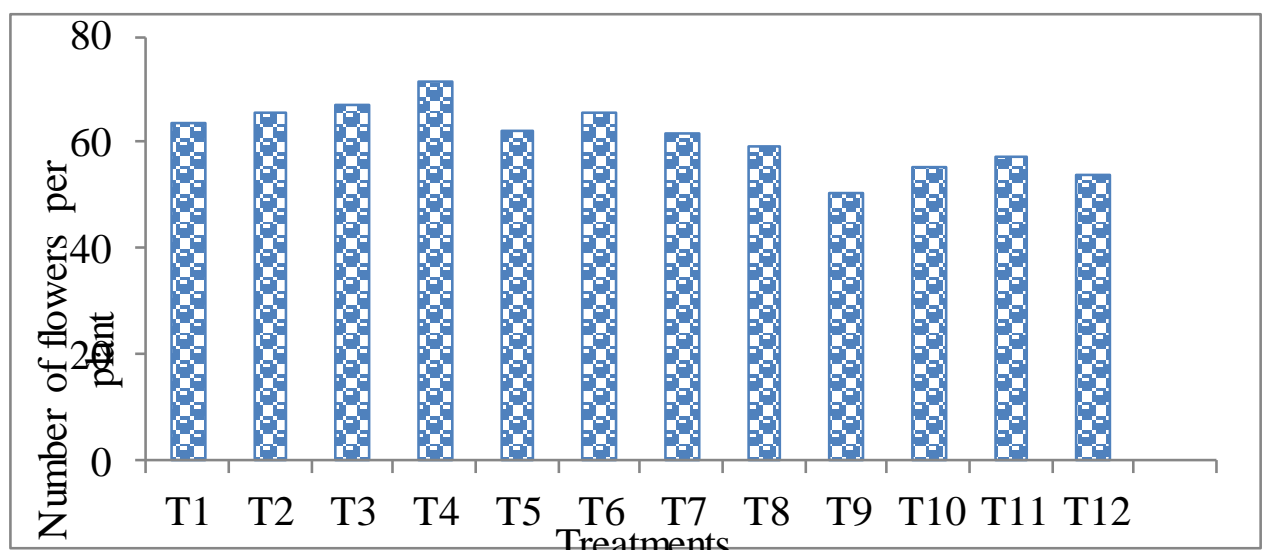

Figure.2 Effect of different plant growth regulators on Number of flowers per plant of China aster cv. Shashank

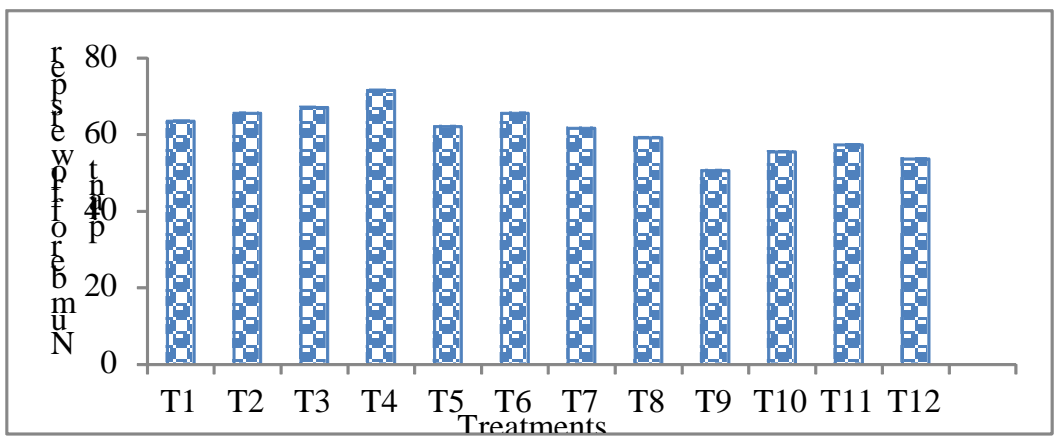

Figure.3 Effect of different plant growth regulators on Flower yield per hectare $(\mathrm{t} / \mathrm{h})$ of China aster cv. Shashank

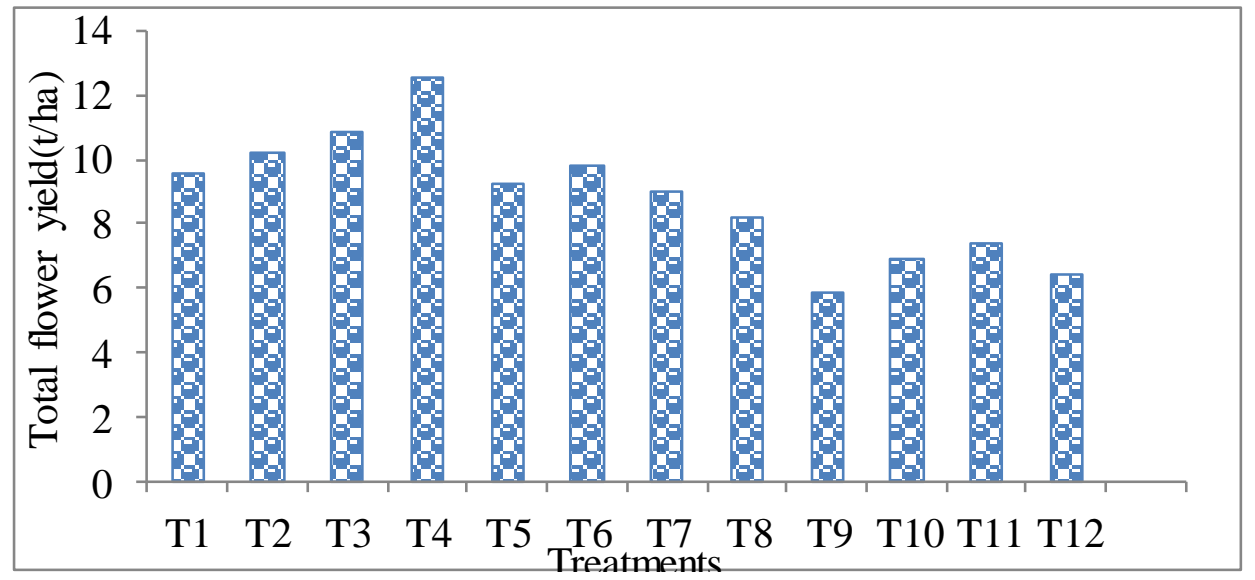


Table.1 Effect of different plant growth regulators on yield of China aster cv. Shashank

\begin{tabular}{|c|c|c|c|c|c|c|}
\hline $\begin{array}{c}\text { Treatment } \\
\text { No. }\end{array}$ & Treatments & $\begin{array}{l}\text { Number of } \\
\text { flowers per } \\
\text { plant }\end{array}$ & $\begin{array}{c}\text { Flower } \\
\text { weight } \\
(\mathrm{g})\end{array}$ & $\begin{array}{c}\text { Flower } \\
\text { yield/plant } \\
(\mathrm{g})\end{array}$ & $\begin{array}{c}\text { Flower } \\
\text { yield/plot } \\
\text { (g) }\end{array}$ & $\begin{array}{c}\text { Total flower } \\
\text { yield(t/ha) }\end{array}$ \\
\hline $\mathrm{T}_{0}$ & Control & 33.89 & 2.93 & 99.275 & 1191.3 & 3.17 \\
\hline $\mathrm{T}_{1}$ & $\mathrm{GA}_{3} @ 50 \mathrm{ppm}$ & 63.5 & 4.73 & 300.63 & 3607.62 & 9.62 \\
\hline $\mathrm{T}_{2}$ & $\mathrm{GA}_{3} @ 100$ ppm & 65.50 & 4.9 & 320.65 & 3847.88 & 10.26 \\
\hline $\mathrm{T}_{3}$ & $\mathrm{GA}_{3} @ 150 \mathrm{ppm}$ & 67.01 & 5.06 & 339.40 & 4072.84 & 10.86 \\
\hline $\mathrm{T}_{4}$ & $\mathrm{GA}_{3} @ 200 \mathrm{ppm}$ & 71.54 & 5.5 & 393.42 & 4721.04 & 12.58 \\
\hline $\mathrm{T}_{5}$ & NAA @ 50 ppm & 62.09 & 4.65 & 289.08 & 3469.04 & 9.25 \\
\hline $\mathrm{T}_{6}$ & NAA@ 100 ppm & 65.49 & 4.7 & 307.14 & 3685.76 & 9.82 \\
\hline $\mathrm{T}_{7}$ & NAA@ 150 ppm & 61.63 & 4.56 & 281.35 & 3376.21 & 9.00 \\
\hline $\mathrm{T}_{8}$ & NAA@ 200 ppm & 59.16 & 4.36 & 258.46 & 3101.62 & 8.27 \\
\hline $\mathrm{T}_{9}$ & CCC@ 500 ppm & 50.58 & 3.63 & 183.59 & 2203.08 & 5.87 \\
\hline $\mathrm{T}_{10}$ & CCC @ 1000 ppm & 55.4 & 3.9 & 215.94 & 2591.34 & 6.91 \\
\hline $\mathrm{T}_{11}$ & CCC @ 1500 ppm & 57.29 & 4.06 & 232.94 & 2795.35 & 7.45 \\
\hline \multirow[t]{4}{*}{$\mathrm{T}_{12}$} & CCC @ 2000 ppm & 53.62 & 3.75 & 201.29 & 2415.59 & 6.44 \\
\hline & F-test & S & $\mathbf{S}$ & $\mathbf{S}$ & $\mathbf{S}$ & $\mathbf{S}$ \\
\hline & S.Ed. $( \pm)$ & 0.86 & 0.48 & 30.49 & 365.93 & 0.98 \\
\hline & C.D.at 5\% & 1.78 & 0.98 & 62.94 & 755.25 & 2.01 \\
\hline
\end{tabular}

Table.2 Economics for different treatments of China aster cv. Shashank

\begin{tabular}{|c|c|c|c|c|c|}
\hline $\begin{array}{c}\text { Treatment } \\
\text { No. }\end{array}$ & Treatment & $\begin{array}{c}\text { Cost of } \\
\text { cultivation } \\
\text { (Rs.ha }^{-1} \text { ) }\end{array}$ & $\begin{array}{c}\text { Gross } \\
\text { Return }^{-1} \\
\left(\text { Rs.ha }^{-1}\right)\end{array}$ & $\begin{array}{l}\text { Net Return } \\
\text { (Rs.ha }^{-1} \text { ) }\end{array}$ & $\begin{array}{c}\text { Benefit Cost } \\
\text { Ratio }\end{array}$ \\
\hline $\mathrm{T}_{0}$ & Control & $1,13,439$ & $1,58,840$ & 45,401 & $1.4: 1$ \\
\hline $\mathrm{T}_{1}$ & $\mathrm{GA}_{3} @ 50 \mathrm{ppm}$ & $1,14,764$ & $4,81,016$ & $3,66,252$ & $4.19: 1$ \\
\hline $\mathrm{T}_{2}$ & $\mathrm{GA}_{3} @ 100 \mathrm{ppm}$ & $1,16,089$ & $5,13,051$ & $3,96,963$ & $4.41: 1$ \\
\hline $\mathrm{T}_{3}$ & $\mathrm{GA}_{3} @ 150 \mathrm{ppm}$ & $\mathrm{c} 1,17,414$ & $5,43,045$ & $4,25,632$ & $4.62: 1$ \\
\hline $\mathrm{T}_{4}$ & $\mathrm{GA}_{3} @ 200 \mathrm{ppm}$ & $1,18,739$ & $6,29,473$ & $5,10,734$ & 5.30:1 \\
\hline $\mathrm{T}_{5}$ & NAA @ 50 ppm & $1,13,868$ & $4,62,538$ & $3,48,670$ & $4.06: 1$ \\
\hline $\mathrm{T}_{6}$ & NAA@ 100 ppm & $1,22,052$ & $4,91,435$ & $3,69,384$ & $4.02: 1$ \\
\hline $\mathrm{T}_{7}$ & NAA@ 150 ppm & $1,14,727$ & $4,50,162$ & $3,35,435$ & $3.92: 1$ \\
\hline $\mathrm{T}_{8}$ & NAA@ 200 ppm & $1,15,156$ & $4,13,549$ & $2,98,393$ & $3.59: 1$ \\
\hline $\mathrm{T}_{9}$ & CCC @ 500 ppm & $1,13,704$ & $2,93,744$ & $1,80,040$ & $2.58: 1$ \\
\hline $\mathrm{T}_{10}$ & CCC@ 1000 ppm & $1,13,969$ & $3,45,512$ & $2,31,543$ & $3.03: 1$ \\
\hline $\mathrm{T}_{11}$ & CCC @ 1500 ppm & $1,14,234$ & $3,72,713$ & $2,58,480$ & $3.26: 1$ \\
\hline $\mathrm{T}_{12}$ & CCC @ 2000 ppm & $1,14,287$ & $3,22,079$ & $2,07,792$ & $2.81: 1$ \\
\hline
\end{tabular}


These results are in agreement with those reported by Rakesh et al., (2003) in chrysanthemum. The increase in yield and yield parameters with $\mathrm{GA}_{3}$ spraying was due to better crop growth, thus increased the number of flowers per plant and ultimately increased the flower yield. This can be attributed to translocation of source to sink. Similar results were reported by Doddagoudar (2002), kumar et al., (2003), Nandre et al., (2009), Shrikanth et al., (2011) and Kumar (2012) in China aster.

In conclusion, among all the treatments applied the treatment $\mathrm{GA}_{3}$ at $200 \mathrm{ppm}$ registered as the best in all the characters than other treatments, so application of $\mathrm{GA}_{3}$ at 200 ppm will lead to get higher yield.

\section{Acknowledgement}

I wish to express my sincere gratitude to $\mathrm{Mr}$. Dr. V.M. Prasad, Professor and Head, Department of Horticulture, SHUATS, Allahabad for providing me an opportunity to do my project work in Department of Horticulture, Naini Agriculture Institute, Sam Higginbottom university of Agriculture, Technology and Sciences (SHUATS), during the year 2016-17.

\section{References}

Doddagoudar, S.R., Vyakaranahal, B.S., Shekhargouda, M., Naliniprabhakar, A.S., and Patil, V.S. 2002. Effect of mother plant nutrition and chemical spray on growth and seed yield of China aster cv. Kamini. Seed Research. 30(2): $269-274$.

Kumar, E.K. 2012. Studies on the effect of plant growth regulators on growth, flower yield and vase life of China aster [Callistephus chinensis (L.) Ness.] cv. Kamini in coastal districts of Andhra Pradesh. M.Sc. (Hort.) thesis submitted to the Dr.Y.S.R Horticultural University, Tadepalligudem (AP).

kumar, P., Raghava, S.P.S., Misra, R.L., and Singh, K.P. 2003. Effect of GA3 on growth and yield of China aster. Journal of Ornamental Horticulture. 6(2): 110 112.

Munikrishnappa, P.M., and Chandrashekar, S.Y. 2014. Effect of growth regulators on growth and flowering of China aster (Callistephus chinensis L. Nees) Agriculture Reviews. 35 (1): 57-63.

Nandre, D.R., Navandar, U.O, and Archana, D.W. 2009. Effect of growth regulators on growth, flowering and yield of China aster. Asian Journal of Horticulture. 4(1): 50-51.

Rakesh, Singhrot, R.S., and Beniwal, B.S. 2003. Effect of $\mathrm{GA}_{3}$ and pinching on growth and yield in chrysanthemum. South Indian Horticulture. 32(1\&2): 6163.

Shrikanth, L.G.; Gopinath, G. and Krishna Manohar, R. 2011. Influence of growth regulators on quality, yield and economics of China aster [Callistephus chinensis (L) Nees]. Mysore Journal of Agricultural Science. 45(4): 815-818.

\section{How to cite this article:}

Mamilla Sindhuja and Prasad, V.M. 2018. Effect of Different Plant Growth Regulators and their Levels on Floral Yield and Economics of China Aster [Callistephus chinensis (L.) Nees] cv. Shashank. Int.J.Curr.Microbiol.App.Sci. 7(12): 1208-1212.

doi: https://doi.org/10.20546/ijcmas.2018.712.150 